\title{
Pluralism in the perspective of Semitic religions
}

\author{
Biyanto \\ State Islamic University Sunan Ampel, Indonesia \\ Email:mr_abien@yahoo.com \\ DOI: $10.18326 /$ ijims.v5i2.255-282
}

\begin{abstract}
This article explores the concepts of religious pluralism in the perspective of Semitic religions: Judaism, Christianity, and Islam. As Semitic religions, the three actually share some teaching similarities in the field of theology. But, in so a long history development, it turns out that there are some differences in their theological teachings. The power history and politics factors have also influenced the relation between the followers of the Semitic religions. Therefore, it is important to explore deeply the concepts of pluralism in the three religions and also the development of the thoughts about the religious pluralism among the philosophers and theologians in each of the religion. This is due to the fact that in this present context, all religions in this globe face similar problems dealing with the pluralism where one of the indicators is the occurrence of radicalism even terrorism cases involving the followers of each religion. The triggering factor is that the followers of each religion are not ready to live in diversity. It is due to the high amount of socio-religion-nuanced radicalism cases that a number of thinkers from the three religions have been trying to reformulate the meanings of pluralism in the present context with the target to have some active involvements among the followers of the Semitic religions to solve the plurality problem. At present there is some awareness among the thinkers that each group of religion should not have
\end{abstract}


some thoughts that they are the best, and it is only they that possess the heaven. Such a claim is growing from a group's subjectivity. If this happens, it means that there is a threat to any efforts in implanting the values of pluralism.

Artikel ini membahas konsep pluralisme keagamaan dalam perspektif agamaagama semitik, yakni Yahudi, Kristen, dan Islam. Sebagai agama semitik atau agama samawi, tiga agama tersebut sebenarnya memiliki kesamaan ajaran di bidang teologi. Tetapi dalam perkembangan sejarah yang begitu panjang ternyata ada beberapa ajaran teologi yang berbeda. Faktor sejarah dan politik kekuasaan juga berpengaruh terhadap hubungan pemeluk tiga agama wahyu tersebut. Karena itu penting ditelaah secara mendalam konsep pluralisme tiga agama tersebut. Juga penting dibahas perkembangan pemikiran tentang pluralisme keagamaan di kalangan filsuf dan teolog dari masing-masing agama. Sebab, dalam konteks kekinian semua agama di dunia ini menghadapi problem yang sama berkaitan dengan pluralisme. Diantara indikatornya, masih sering terjadi kasus radikalisme, bahkan terorisme, yang melibatkan pemeluk masing-masing agama. Jika dlacak faktor pemicunya adalah ketidaksiapan pemeluk masingmasing agama untuk hidup dalam kemajemukan. Seiring dengan banyaknya kasus radikalisme sosial bernuansa agama itulah sejumlah pemikir dari tiga agama semitik tersebut telah berupaya untuk merumuskan kembali makna pluralisme dalam konteks kekinian. Targetnya adalah adanya keterlibatan yang aktif antarpemeluk agama semitik untuk mengatasi problem pluralitas. Kini ada kesadaran di kalangan pemikir agama-agama semitik bahwa setiap kelompok tidak dibenarkan merasa paling unggul dan menganggap kelompok lain tidak berarti. Juga tidak dibenarkan ada klaim kebenaran bahwa surga hanya milik kelompok tertentu. Klaim tersebut jelas tumbuh dari subjektifitas kelompok. Jika itu terjadi berarti ancaman terhadap usaha untuk membumikan nilainilai pluralisme.

Keywords: Diversity; Religious pluralism; Semitic religions; Tolerance

\section{Introduction}

The discourse of religious pluralism has actually emerged at the beginning of the development of Islam, especially during the conquering process of Moslems over non Moslems. The interaction among the Moslems 
in this period was legitimated in the Islam law giving some assurance to the rights of the non Moslems. This assurance was especially given to the scribers (Judaism and Christian) to do their religion teachings as long as they were loyal to and was willing to pay some tributes to the Moslems leaders. This history reality shows from the beginning that the leaders of Islam have had some awareness to build a harmonious life order over the diversity of cultures, ethnic groups, races and religions.

In this present context, the discourse of pluralism is not only discussed in terms of the reality of the diverse and complex society, consisting of various races and religions, but also in the context of building some genuine engagement of diversities within the bounds of civility. Even, it can be said that pluralism is a necessity for saving the human beings that may be made among others through the mechanism of supervising and balancing among any groups in the society. ${ }^{1}$ It means that this perspective places pluralism as a religious typology which is the further stage of inclusivism. Inclusivism necessitates an understanding that other religions possess similarities so that there is a desire to have a meeting point among the religions. Different from inclusivism, pluralism exactly recognizes the differences. ${ }^{2}$

It is in this context that pluralism may be considered as a continuance from inclusivism since it sees each religion possess a unique reality. Then, here pluralism is present to build some tolerance amid the religions differences and diversities. ${ }^{3}$ The problem of diversity is not only experienced by Islam, but also realized by other religions. Therefore, Harold Coward

${ }^{1}$ Budhy Munawar Rachman, Islam Pluralis: Wacana Kesetaraan Kaum Beriman, Jakarta: Paramadina, 2001, 31.

'Zuhairi Misrawi, Al-Qur'an Kitab Toleransi: Inklusivisme, Pluralisme, dan Multikulturalisme, Jakarta: Fitrah dan Perhimpunan Pengembangan Pesantren dan Masyarakat, 2007, 205. 206.

${ }^{3}$ Asrori S. Kirani, "Jembatan Ayat Keras dan Lunak," Gatra, Number. 10, Volume XIV (17-23 January 2008), 44-45. 
(born, 1936) states that pluralism may actually be found out in each religion. According to Harold, great religions, Judaism, Christianity, Islam, Hinduism, and Buddhism, clearly have normative teachings and historical experiences in facing the society's plurality problem. ${ }^{4}$ But, in John Hick's perspective, Islam seems to have a more clear view on pluralism. According to John Hick (1922-2012), it is because Islam has a doctrine on the scribers (ahl al-kitab) covering Judaism and Christianity. ${ }^{5}$ Among the thinkers of Islam, the discourse of the scribers is also debated so that this issues seems to be controversial. Therefore, it is necessary to explore deeply the the concept of pluralism in the perspective of the Semitic religions.

\section{Understanding the religious pluralism}

Etymologically, pluralism is from the word plural, meaning more than one. In the dictionary, the word plural means an adjective used with reference to more than one. ${ }^{6}$ In the tradition of philosophy, the meaning of philosophy is often compared with that of monism, meaning the concept of unity in many respects. Pluralism may also be distinguished from dualism that sees the world as an entity with two different things. ${ }^{7}$ Monism is from Greek monos, meaning singular. This term was firstly introduced by German Christian Wolff (1679-1754), to show a a concept stating that the nature of the whole existence is from one source. For materialists, material is the base for the formation of the world. Meanwhile

${ }^{4}$ Harold Coward, Pluralism Challenge to World Religion, Maryknoll, NY: Orbis Books, $1985,1-88$.

5John Hick, "Trinity and Incarnation in the Light of Religious Pluralism," in Three Faith One God: A Jewish, Christian, Muslim Encounter, eds. John Hick and Edmund S. Meltzer, Albany: State University of New York Press, 1989, 197-199.

${ }^{6}$ A. S. Hornby et. al., The Oxford Advanced Learner's Dictionary of Current English, Oxford: Oxford University Press, 1984, 642.

${ }^{7}$ Anthony Flew, A Dictionary of Philosophy, New York: St. Martin's Press, 1984, 273. Compare with "Pluralism," Encyclopedia of Religion and Ethics, Volume X, ed. James Hastings, New York: Charles Scribner's Sons, 1955, 66-67. 
the idealists state that the base for the formation of the world is spirits of ideas. ${ }^{8}$ Monism was firstly discussed in the context of the problematic relation between mind-body as the qualification parameter. Some philosophers merely acknowledge the existence of thought, some, the existence of body.

Dualism is from Latin dualis, meaning two. This term has been introduced by Thomas Hydes in 1700 and was used by Christian Wolff (16791754) to show a metaphysical opposition between mind and material. Dualism is a school seeing anything as two. ${ }^{9}$ Dualism has been used to refer to a bad-good conflict Ormazd and Ahriman in the Zoroastrianism tradition. The Zoroastrian philosophy tradition also sees that the world is divided into dark and bright condition. Another example is Rene Descartes (1596-1650) contrasting between mind and matter. The further development shows that dualism has been used in many oppositions in religion, metaphysics, and epistemology. Therefore, dualism is a philosophical view that confirms the existence of the two fields that are separated, cannot be reduced and are unique, for examples supernatural-natural, God-universe, spirit-material, mind-body, visible-invisible, sensual-intellectual, actual-possible realities, noumenal-phenomenal worlds, good-bad powers. According to the followers of dualism, all phenomena may be explained in the context of the opposition between two different realities.

Pluralism is also used in the socio-political term as a system that recognizes the coexistence of the diversity either in race, ethnic group, ideology, culture, or party while still keeping the very unique differences well among the groups. American political scientist, Henry S. Kariel (19242004), proposes six general propositions which are integrated in the theory

${ }^{8}$ Anthony Flew, A Dictionary..., 273 and 377.

${ }^{9}$ Anthony Flew, A Dictionary..., 97. 
of pluralism politics; (1) individuals are represented in some small units of government, (2) unrepresentative government administration results in chaos, (3) society consists of various associations of religions, cultures, education, professions, and economy which stand alone, (4) the associations are voluntary, meaning that there is no necessity for anyone to affiliate to an association, (4) the accepted and binding public policy is the result of free interaction among associations and (6) public government is obliged to recognize and to act merely on the common denominator. ${ }^{10}$ The propositions show that the idea of the political pluralism in this modern age may be made as a model of reformation framework.

The socio-political meaning of pluralism shows that pluralism not only signal some willingness to recognize the right of other groups, but also act justly to other groups on the basis of peace and respect one another. This attitude should be showed off, since a nation-state, even the most harmoniously geographical entity still shows the diversity of races, ethnic groups and religions. This also happens to any political and ideological ideas that must reflect some natural differences in thoughts and evaluation. Especially, after the global era with its all consequences, such a diversity has become reality that should be intellectually or morally accepted. In this case it is important to set out some understanding of pluralism stressing that minority groups may play some roles together with majority groups in full and equal manners in the society while still maintaining their identity and uniqueness.

Pluralism is more than moral tolerance or passive coexistence, since tolerance is the matter of habit or of personal feelings. While coexistence is acceptance to other parties different from oneself with some efforts to eliminate any conflicts. On the one hand, pluralism presupposes

${ }^{10}$ Henry S. Kariel, "Pluralism," International Encyclopedia of the Social Sciences, Volume 11, ed. David L. Sills, New York: The Macmillan Company and The Free Press, 1996, 164. 
some protected institutional measurements and legitimates some equality and develops brotherhood among human beings personally or in groups, whether the measurement is innate or acquired. Pluralism also requires a serious approach to any effort to understanding others and to constructive cooperation for goodness for all. Each person should enjoy equal rights and opportunities, and fulfill equal obligation as citizens. Each group should also possess rights to come together in a place and to develop, and to maintain their own identity and interest, and to enjoy their equal rights and obligations. ${ }^{11}$

Meanwhile, Abdul Aziz Sachedina (born, 1942) states that pluralism is one of the most concise words to mention a new world order where differences in cultures, belief systems, and in values should be realized by each and every citizen in order to make them able to live in peace in differences. ${ }^{12}$ Such a statement is made by Sachedina since cultural diversity may have potency to results in unending conflicts. The history of the relation among members of religious communities proves that diversity of religions and beliefs may cause eternal conflicts involving the Christians and Moslems. The recent phenomenon in Indonesia also shows some social stringency in some areas under the name of religion and religious views. This reality demonstrates that it is necessary to always grow some awareness among members of religious communities to recognize others' human dignities regardless of their religions, races and their cultural affiliations.

The religious word in the chain of the word religious pluralism is intended to show some aspects related to the quality of one's full and total

\footnotetext{
${ }^{11}$ Mohammed Fathi Osman, Islam, Pluralisme dan Toleransi Keagamaan: Pandangan alQur'an, Kemanusiaan, Sejarah, dan Peradaban, trans. by Irfan Abu Bakar, Jakarta: PSIK Universitas Paramadina, 2006, 2-3.

${ }^{12}$ Abdul Aziz Sachedina, Kesetaraan Kaum Beriman: Akar Pluralisme Demokratis dalam Islam, trans. by Satrio Wahono, Jakarta: Serambi, 2002, 48.
} 
comprehension and attitudes on the basis of the values of her or his religious teachings. In social studies, religious terms are usually distinguished from the word religion. According to Mukti Ali (1923-2004), religion is the most difficult word to be given meaning. He says that at least there are three reasons why it is difficult to define the word religion. First, since religious experiences are spiritual matters and are often subjective, therefore it is very individual. Second, perhaps people who talk about their religion must show more enthusiasm and emotions. Therefore, when talking about religions, people always have strong emotions. Third, the conception of religion will be influenced by the intention of the person that gives the understanding. In other words, religion is difficult to define on the basis of the perspective one adopts. ${ }^{13}$

The difficulties in giving the understanding of religion that may be commonly accepted are also reflected through the views of philosophers, sociologists, psychologists, and theologians. Philosophers, for instance, see that religion is a superstitious structure of incoherent metaphisical notions. Sociologists define religion as a collective expression of human values. Then the followers of Karl Marx (1818-1883) interpret religion as the the opiate of the people. And Psychologists conclude the term religion as the mystical complex surrounding a projected super ego. From the various views, it is clear that there is no limitation agreed upon the word religion. ${ }^{14}$ Although it is difficult to find out a perfect understanding of religion, sacred and profane separation, belief in soul, belief in God, acceptance of supernatural revelations, and some search for salvation. ${ }^{15}$

${ }^{13}$ A. Mukti Ali, Agama, Universitas, dan Pembangunan, Bandung: Badan Penerbit IKIP, 1971, 4.

${ }^{14}$ John R Benner, "Religion," in Encyclopedia Americana, Volume 29, Canada-USA: American Sorporation, 1978, 342.

${ }^{15}$ John R Benner, "Religion," in Encyclopedia Americana, Volume 29, Canada-USA: American Sorporation, 1978, 342. 
Popularly, religion is also interpreted in a theological understanding as divine revelations given by God to prophets and messengers as the life guideline for human beings. In this perspective, religion may means as the collection of doctrines, teachings and standard laws believed as the codification of God's instruction to human beings.

Besides religious pluralism, there are also various terms used in some literatures to show the diversity phenomenon in religiousness. The figures such as Richard Huges Seager, ${ }^{16}$ Thomas Dean, ${ }^{17}$ and Kosuke Koyama, ${ }^{18}$ are those who make use of the term religious diversity. ${ }^{19}$ Such various uses shows that pluralism has been one of the themes that have been discussed by a lot of inter-religious thinkers. Therefore, it is not exaggerated when Harold Coward states that pluralism is a challenge each religion faces at present. Even, referring to the religiousness tradition, each religion turns out having various doctrines and experiences in facing the pluralism problem. ${ }^{20}$ Thus, pluralism means that a religion cannot close itself anymore and consider that its teachings and the ritual system are the most valid ones.

\section{Pluralism in the perspective of Judaism}

According to Harold Coward, Judaism may be used as the early reference of religious pluralism. Coward's opinion is based on two arguments; first, Judaism is the first religion that teaches monotheism in its form and

\footnotetext{
${ }^{16}$ Richard Huges Seager (ed), The Dawn of Religious Pluralism: Voices from the World Parliament of Religion 1893, Illionis: Open Court Publishing Company, 1993.

${ }^{17}$ Thomas Dean (ed), Religious Pluralism and Truth: Essays on Cultural Philosophy of Religion, Albany: State University of New York Press, 1995.

${ }^{18}$ Kosuke Koyama, Kosuke Koyama, "A Theological Reflection on Religious Pluralism," in http://www.findarticles.com/cf_0/m2065/2_51/56063939/print.jhtml, (8 Pebruari 2003).

${ }^{19}$ Gerald Parsons (ed), The Growth of Religious Diversity Britanian from 1945, London: Routledge, 1993.

${ }^{20}$ Harold Coward, "Preface," in Pluralism..., vii-viii.
} 
faith. Other monotheistic religions, Christian and Islam, have made Jewish to have contexts in its emergence and teachings. Therefore, it is rather similar relationship between Hinduism and Buddhism in the East World. The relatedness between Judaism, Christian and Islam, that teach monotheism, have made Jewish philosophers and theologians investigate their teachings in relation to other teachings of religions.

Second, religious pluralism in Judaism is mostly related to its followers' life experiences. They possessed the experiences called diaspora, namely life in the religious community spread all over the world. Jewish people live as minority groups among other religions communities. Since 586 BC, Jewish community has started to spread and disperse when Jerussalem fell down. For more than two and half decade, the Jews have had experiences to struggle and to defend the identity of "Jew" among the domination of other traditions. These experiences require them to formulize their religious faith and practice continuously. Their condition worsened when they faced a challenge of mass assassination during Hitler's administration. It means that Hitler had raised a new problem for Jewish community. The problem deals with how does one sing the Lord's song in an alien land? ${ }^{21}$

During the classical and middle periods, Jew thinkers had made the relationship between Judaism and other religions as a discourse. Philo (20 BC-50 AD), a loyal follower of Plato (428-348 BC), stated that various Greek religions and philosophies were the different realizations of one Logos, God. Meanwhile Maimonides (1135-1204), the most important thinker of Judaism in the Middle age, studied ideas of Greek philosophies and Islamic theology, said that from all religions, Judaism is one of religious faiths revealed by God. It is merely the religious faith in the perspective of Judaism

\footnotetext{
${ }^{21}$ Harold Coward, "Preface," in Pluralism..., 1.
} 
that is right in all respects. Although Maimonedes's religious concept is very narrow, he was still tolerant with the teachings of Christian and Islam. For example, it is said that the teachings brought by Jesus and Muhammad are a part of Allah's policy. He also positively appreciated the teaching of Christian that regards that Taurat is a holy scripture. To Islam, he prized it because the theological doctrine of Islam teaches refusal to the practice of worshipping idols. He was even very rational when saying that the unbelievers if being capable of showing themselves as pious persons have rights to obtain happiness in the world to come. ${ }^{22}$

At the end of the Middle age, the Kabbala tradition which had strong influences to the Jew history emerged. For exampe Moses de Leon (12501305) revealed many Gnostic and Neoplatonic teachings. God is seen as the absolute beyond all human beings' prediction. Kabbala's ways of thinking are similar to the Logos tradition of Philo about the one absolute with many realizations, the One Supreme God as realized in various religions. Jews' responses to the idea of pluralism may be grouped into three lines of thoughts, namely the emancipation movement from Moses Mendelssohn in XVIII century, the European thoughts from Franz Rosenzweig (1886-1929) and the American echumenic perspective from thinkers such as Abraham Joshua Heschel (1907-1972). Mendelssohn (1729-1786) tried to bridge the gap of Jew in the middle age and the modern Europe. He stated that he had many opinions which are the same with those of Immanuel Kant (1724-1804) who appreciated the intellect. He said that the religion truth did not depend on the God's revelation, but it is immanent in the intellect of each person.

Mendelssohn could not understand the way of thinking stating that God reveals the truth merely to some, not all, human beings. It means

\footnotetext{
${ }^{22}$ Harold Coward, "Preface," in Pluralism..., 5.
} 
that those with no revelation do not have any chance to feel any happiness. There is no religion that may be used by God as the only tool to reveal the truth. For Mendelssohn, Judaism never thinks itself to possess an exclusive revelation on the truth for salvation. The revelation is available for all people through their intellect. Therefore, it means that all religions should convey the truth the God gives through intellect, though each religion has a sets of unique rule to give meanings and guidance in the life in the world.

Franz Rosenzweig clarified his standpoint of other religions as the reaction to the idealism of George Wilhelm Hegel (1770-1831). Different from Hegel's view on the universal idea, Rosenzweig focused his attention to the whole relationship among human beings, the world and God. All of them are revealed in Judaism and Christian, not in others. Whereas, the modern American Jewish thinkers state that all religions are the realization of God's commandments. Religion diversity should be seen as positive elements which are the struggles of the community of a religion in responding secular powers around it creatively. The modern Jewish thinkers' views were rather stained by Zionism movement which then bore the State of Israel. But, in the case of Zionism, it should also be remembered that a religion as a whole if mixed with political and national interests will show its exclusive characteristics. It is what happens to Zionism which then shows itself as an exclusive movement. Even in many latest occurrences, Zionism has demonstrated extraordinary cruelties not only for Moslems but also for International world.

\section{Pluralism in the perspective of Christianity}

The doctrine of Christian also shows an awareness that the religious pluralism may become a challenge for the Christian community to build a relation with other religions. The main problem the Christianity faces is 
the necessity to believe in the unique Christian teaching such as the doctrine of God's reincarnation in Christ. Moreover, the doctrine also puts forward many exclusive teachings that may close dialogues with the communities of other religions. For instance, Christian teachings state that Christ is the only valid way for salvation. This exclusive view has dominated the Christian circle for centuries.

Besides such an exclusive view, there are also some thoughts from Christian thinkers considered as inclusive. This inclusive view acknowledges the presence and activities of salvation the God makes through all religion traditions. The document showing such inclusiveness may be found in "The Declaration of the Relationship between Churches and Non-Christianitys (Nostra Aetate)". The document was disseminated by Pope Paulus VI on October 28, 1965. In the document a new approach to non Christians, especially those dealing with Moslem was suggested. ${ }^{23}$ Another important document presented is "Alight for Non-Christians (Lumen Gentium)." This documents adopt a view stating that Salvation is also possible for the people beyond the Church. ${ }^{24}$

The statements clearly explain that among the Christian people, some awareness has existed as realized in the act of asking the ummah of Islam to forget various dark incidents in the past. The Ummah Christianity and Islam should try to understand one another and integrate peace, freedom, social justice and moral values together. Recognition of the communities of other religions may also grow the Christian Mission in inter-religious dialogues. So, it is not exaggerated to state that the Roman Catholic Church during the era of Vatican II actually changed its Christian theologians' perception that out of the Church, salvation ex-

\footnotetext{
${ }^{23}$ Charles Kimbal, Kala Agama Jadi Bencana, trans. Nurhadi, Bandung: Mizan, 2003, 298.

${ }^{24}$ Charles Kimbal, Kala Agama..., 298.
} 
ists. This had not been recognized before.

Besides the exclusive and inclusive views, there are also some Christian thinkers with pluralistic thinking. This thinking really emphasizes the continuation of various diversity traditions. By this thinking, pluralistic Christian thinkers do not see again the Christian tradition as the only way towards salvation. The main figures supporting pluralism in Christian are John Hick, a well-known English religion philosopher and theologian. Using an analogy in the astronomy, John Hick proposed a theocentric approach, it is a shift from the dogma that the Christianity was at the centre of awareness and God was at the centre and all religions devoted and revolved around Him. ${ }^{25}$

In presenting his ideas, John Hick made a comparison between Ptolomeus' and Copernicus' theories on the Solar system. Ptolomeus' astronomy theory states that the earth was the centre of the solar system in which all planets revolved around it. This theory has a theological implication that Christ is the center of all religions, meaning that other religions would revolve around Christianity. John Hick stated that it is probable that the analogy of the Ptolomeus' theory also happened to other religions. For example, a follower of Hinduism may believe that the followers of other than Hinduism are also Hindu people. Other religions are ordinary ways, while Hinduism is an extra one. The truth in Hinduism is eternal, it may evaluate the teachings of other religions. It is the religious faith that will emerge when one makes use of the model of the Ptolomeus's theory. Using the analogy of Copernicus's theory stating that the sun is the center of the solar system, John Hick says:

We have to realize that the universe of faith centers upon God, and not upon Christianity or any other religion. God is the sun, the origina-

\footnotetext{
${ }^{25}$ Charles Kimbal, Kala Agama..., 300.
} 
tive source of light and life, whom all the religions reflect in their own different ways. If this is so, then it is so to be expected that God, as reflected in the different civilizations, manifests in different revelations or religions. But even though the various revelations differ, we may believe that everywhere the One God has been at work pressing in upon the human spirit. ${ }^{26}$

The Copernican tradition leads John Hick to criticize the Christian doctrine in the New Testament stating the uniqueness of Christ. For example it is stated, "Allah and Father are one, no one comes to Father, except it is through me." John Hick, as he admits himself, is really inspired by an expression made by Bhagavad Gita; "Whatever path men choose is mine." ${ }^{27}$ This expression then inspired John Hick so that he came to a conclusion that God has many names. He stated that the tradition of the world religions should be understood as different responses to the reality of God. Some differences occurring among religious people emerge as the result of diversity of perceptions conditioned by the environment of histories and cultures. ${ }^{28}$

A Christian thinker with a great concern with developing pluralism is Wilfred Cantwell Smith (1916-2000). He is a Canadian professor of comparative religion in McGill University and contributes to the development of Institute of Islamic Studies. Moreover, he is also the Director of Harvard University's Center for the Study of World Religions, a center of study designed to develop dialogues among great religions in the world. In order to reach his intention, Smith always brought academic community of McGill and Harvard and asked them to develop and to test their

\footnotetext{
${ }^{26}$ Harold Coward, Pluralism..., 29.

${ }^{27}$ Harold Coward, Pluralism..., 29.

${ }^{28}$ John Hick, Tuhan Punya Banyak Nama, trans. Amin Ma'ruf and Taufiq Aminuddin, Yogyakarta: DIAN/Interfidei, 2006, 9.
} 
own theology. The objective of this activity is to establish a theory that may be accepted by religions and to give academically convincing arguments.

Wilfred Cantwell Smith may be said to represent the group of Christian thinkers which are very liberal developing the idea of pluralism. He was suspicious to the Christian theological framework asserting the interpretation of "we-they" according to Christianity and standing itself when knowing that other religions as an object or even anybody that should be converted, apart from their kindness. He tried to encourage the followers of Christianity, Islam, Judaism and other religions to interpret all faiths teachings comprehensively and justly. For Smith, this dialogue should be realized since any exclusive theological understanding would result in others' religions to be considered as worshipping idols and make their God the same with Gods/Goddess. This exclusive trait may happen to all followers of religions and is the mirror of arrogance in being religious. According to Smith, all religions lead to the end, God. Therefore, the Christian theology is not allowed to be a view coming from a religion or another community. Christian theology should appear when seeing and recognizing oneself as a participant of a world community including all other religions. ${ }^{29}$

Some names may also be said as the developers of pluralism in Christianity such as Huston Smith (born, 1919), Harvey Cox (born, 1929), and Diana L. Eck (born, 1945). They were always stimulating other Christian thinkers to develop ideas of pluralism. Huston Smith is known through one of his canon, The Religion of Man The Religion of Man. ${ }^{30}$ This work is known for presenting a new interesting approach. He in a respected way

\footnotetext{
${ }^{29}$ Harold Coward, Pluralism..., 33.

${ }^{30}$ Huston Smith, Agama-agama Manusia, trans. Saafroedin Bahar, Jakarta: Yayasan Obor Indonesia, 1991.
} 
opened glorious treasures of various religions and asked us to respect and made use of beneficial values stored in them. He was trying to reveal spiritual dynamics of the world religions once gave an vitality in various societies and civilizations. The noble values are shown as the background to face various challenges, crises of values, processes of dehumanization, and the uncertainty of the future. Activists of inter-religious dialogues such as Djohan Effendi (born, 1939) says that Huston Smith had raised our awareness of not losing a grip and of being willing to re-digest the prophetic idealism spirits of liberation brought by religions. Without them, religions will lose their contextual relevance with our life and the challenges we face. In this condition, religions will face long crises. ${ }^{31}$

Harvey Cox has also given important contributions through his work, Many Mansions. In this work he opened discussions on pluralism among Protestant clergymen. Meanwhile, Diana L. Eck in an extraordinary way was being able to document the religious life in the United States during the era of this millennium shift. Due to her great role, Diana was prized a National Medal in Humanity from the President Bill Clinton in 1998. Her theological view was formed by her study on the traditions of other religions and their interaction with the followers of Hinduism, Islam, Buddhism, Judaism, Sikh, and others. It is her personal experiences that participate in forming her articulation to a very coherent pluralist theology.

\section{Pluralism in the perspective of Islam}

The interaction of the ummah of Islam and the followers of other religions has occurred since the beginning of the history of emergence of Islam. The Prophet Muhammad and his friends had also been living side by side with communities of other religions. Even when Muhammad was given credence as the political leader in Madinah, in which various com-

\footnotetext{
${ }^{31}$ Djohan Effendi, "Preface", in Huston Smith, Agama-agama Manusia..., xiii.
} 
munities of religions such as Judaism, Islam and Arabian nations who had not believed in Islam resided. Moreover, each community was still divided into many ethnic groups, of which among them are Bani Quraidah, Nadir, and Qainuqah. ${ }^{32}$ Meanwhile the Arabian nation dwelling in Madinah also consisted of many ethnic groups, among others, especially among others Aus and Khazarj. In order to unite these Arabian ethnic groups, Muhammad was trying to establish brotherhood using the terms Ansar and Muhajirin, without considering the origins of each ethnic groups. Naming Ansar and Muhajirin is the Prophet Muhammad's effort in confirming a brotherhood (ukhuwah) among Arabian ethnic groups.

As a political leader, Muhammad was clearly faced with a very plural society. Therefore, he and communities of non-Islam religion in Madinah then made an agreement known as Madinah Document (mithaq al-madinah). Briefly this document consists of a commitment to appreciate any freedom to have faith, to have common responsibilities, to help one another, to oblige to defend Madinah when any attacks from external parties occur and to recognize that Muhammad is the leader of the people in Madinah. That is why the position of Muhammad and the Madinah Document is called the judge for the people in Madinah. In the Madinah Charter, it seems that there is a clear commitment to make the community in Madinah as one ummah. ${ }^{33}$

Although the relationship between Islam and non-Islam has been weaved since the beginning, the relationship goes up and down. During the Middle Age for instance, closed and loose relationships and even long conflicts between Moslems and Christians in Europe occurred. The

${ }^{32}$ W. Montgomery Watt, Muhammad Prophet and Statesmant, London: Oxford University Press, 1969, 85.

${ }^{33}$ Muhammad 'Abd al-Malik bin Hishām al-Mu'āfirì, al-Sirah al-Nabawì̄ah, Jilid I-II, Ttp: Dār al-Turāth al-'Arabi li al-Tabā'ah wa al-Nash, t.th, 352. 
peak of this tension happened when the followers of the two great religions involved in a conflict in a war which is then known as The Crusades. This war lasted for almost three centuries (1095-1291) and involved almost all power of Christian troops. In the Christian party, some supports to the Crusades also came from other powers in Europe so that it may seen as a multinational power. ${ }^{34}$

The support and legitimation from the Church may also be seen in the Crusade. Pope Urbanus II and the diocese institution even saw that the Crusade is a holy war. Therefore, it is no wonder if there were many bishops who directly entered into the field of battles to to fire up the spirit of the Christian troops. In his speech to mobilize the mass, the Pope stated that the involvement in the Crusades is a part of Christ's instruction. This call was then followed by the diocese institution to forgive Christian people who joined in the Crusade. It is the Pope's legitimation and the promise of the diocese institution that motivated most of the troops in the Crusade. ${ }^{35}$ Such a long war must have raised religious emotions among Christians and Moslems. This religious emotion caused by the memory of the Crusade turns out being able to influence the relationship between Christianity and Islam. As a result, it is not surprising that in each discussion of the relationship between Christianity and Islam in this contemporary era the Crusade at a certain level may hinder any effort to establish inter-religious dialogues.

From the understanding the history of the Islam and non-Islam relation, it can be stated that actually the encountering between Islam and other religions has happened since the Prophet Muhammad. As the last Semitic religion, Islam sees itself as the peak of previous Semitic religions such as Judaism and Christianity. In this case Islam is present as a religion

\footnotetext{
${ }^{34}$ K. Ali, A Study of Islamic History, New Delhi: Idaraiyati Adabiyati, 1980, 247.

${ }^{35}$ Ameer Ali, A Short History of the Saracens, New Delhi: Kitab Bhavan, 1981, 233.
} 
that straighten out and to perfect previous religions considered to deviate from the primordial teachings (tauhid). Harold Coward describes a general perception the Islamic scholars developed in the Middle Age of the non-Islam religions in the context of negative view. For example, it is said that the followers of Buddhism are skeptical people, those of Buddhism are rationalist people denying the matters pertaining the prophet, those of Christianity are Tri-theis people and those of Judaism are the destroyers of the matters pertaining the prophet. The minor view of the scholars is less accurate information. The scholars who analyzed Judaism and Christianity were not often based on teachings of the religions themselves, but on those of Judaism and Christianity as described and evaluated in the Holy Quran. Another information participated in forming the perception was obtained from those conversing their belief into Islam. ${ }^{36}$

Harold Coward added that one of the weaknesses of the middle age Islamic scholars in understanding religions of non Islam was less adequate information from the sources of teaching of religion other than the Islamic teachings. But, in the next development, it is illustrated that the recent Islamic scholars showed great interests in studying non-Islamic religions on the bases on each holy book and the history of each religion. It seems that the expansion of Islam to the East and the migration among educated Moslems to Europe and United States participated in changing the Islamic scholars' view of non-Moslems. It is in India and Western countries that the Ummah of Islam face a situation that placed themselves as the minority groups among the cultural dominations by other religions. ${ }^{37}$ This condition has given a very valuable learning for the Ummah of Islam to be able to interact with the communities having faith of other religions.

\footnotetext{
${ }^{36}$ Harold Coward, Pluralism..., 60-61.

${ }^{37}$ Harold Coward, Pluralism..., 61.
} 
In India and the Far East, the influence of Sufism has given a lesson on the mystical meeting between Islam and other religions. According to the sufi mystic interpretation, as developed by Muhyi al-Din ibn 'Arabi (1165-1240) dan 'Abd al-Karim al-jili (died, 1428), the founder of each religion is one of aspects of the universal Logos, namely Muhammad's revelations. ${ }^{38}$ The sufists not only confirm that the unity of the revelations, but also consider themselves as the protectors of Islam and of other religions. The pioneers of the Ishraqiyyah school, Maulana Jalal al-Din Rumi (1207-1273), depicted the view of the mystical unity of religions using the following illustration, "Though the ways various, the goul is one. Do you not see that there are many roads to the Ka'bah? So if you consider to the roads the variety is great and the divergence infinite, but when you consider the goal, they are all of one accord and one." ${ }^{39}$

The citation explains that there is a real meeting among religions. Therefore, it can be stated that the Sufism teaching has open the way for the ummah of Islam to recognize the truth of other religions. Even, through the recent figures of Sufism such as Frithjof Schuon (1907-1998) and Seyyed Hossein Nasr (born, 1933), a thought of the meeting point among religions to establish the religion pluralism has been developed. ${ }^{40}$ Schuon is a thinker who spends most his time to write the esoteric dimension of the teachings of Islam. His main work with the title of Understanding Islam has given many influences on Nasr's thought. ${ }^{41}$ Perennial philosophy is one of Schuon's important ideas. It is this philosophy which is then developed by Nasr and which becomes the base for his thinking

\footnotetext{
${ }^{38}$ Harold Coward, Pluralism..., 61-62.

${ }^{39}$ Harold Coward, Pluralism..., 62.

${ }^{40}$ Adnin Armas, "Gagasan Frithjof Schuon tentang Titik Temu Agama-agama," Islamia, Volume I, Number 3 (September-Nopember 2004), 9-18. Anis Malik Thoha, "Seyyed Hossein Nasr Mengusung Tradisionalisme Membangun Pluralisme Agama," Islamia, Volume I, Number 3 (September-Nopember 2004), 19-28.

${ }^{41}$ Frithjof Schuon, Understanding Islam, London: Unwin Paperbacks, 1981.
} 
method, especially in the study of religions. This thought certainly may help the minority communities of Moslem to maintain their lives among the cultures of the non-Islam majorities. But it should be acknowledged that the pluralists' view the people of Sufism have developed is very difficult to be accepted by laws and the doctrines of orthodox Islam. ${ }^{42}$

The Islam perception of the non-Islam in the contemporary era showed various views. Referring to the perception of education Moslem and those living as minority groups in the West and the East, a very positive view is found. For instance, it can be shown Muhammad Arkoun's view of the need for inter-religious dialogues, especially among Semitic religions. According to Arkoun, inter-religious dialogues should start from empirical experiences based on the history reality. In developing the inter-religious and civilization dialogues, Arkoun considers that it is important to develop a concept of "Applied Islamology" possessing certain characteristics namely pluralistic in methodology and open to criticism so that it will be free fromany reduction and the restriction of the object of study. This Applied Islamology may be made through two ways. First, modern linguistic theories to understand texts is used, and second, a closed official corpus is used as the base for a wide linguistic and cultural area in which the revelations in the three Semitic religions are approached, interpreted and used. ${ }^{43}$

A positive perspective of the religion pluralism is also given by Sachedina. He says that religion pluralism in a community of people having a religious faith promises the emphasis of the inclusivity principle, meaning it is a condition giving a priority in accommodating various

\footnotetext{
${ }^{42}$ Sani Badron, "Ibn 'Arabi tentang Pluralisme Agama," Islamia, Volume I, Number 3 (September-Nopember 2004), 30-48.

${ }^{43}$ Mohammed Arkoun, Islam Kontemporer Menuju Dialog Antaragama, trans. Ruslani, Yogyakarta: Pustaka Pelajar, 2001, 182.
} 
truth claims of religions in culturally and religiously heterogeneous societies. This inclusive characteristic according to Sachedina may result in the growing sensitivity to various unique possibilities that may enrich human effort to reach spiritual and moral welfare. ${ }^{44}$ Dealing with pluralism in the Islamic tradition, Sachedina states that the revelations of this youngest religion actually may reveal itself in a pluralistic world. Islam recognizes and valuates other religions critically. Islam also never refuses them and consider them wrong. ${ }^{45}$ Even in the Holy Quran it is confirmed that human beings is one ummah and God stores powers to unite human beings into one. ${ }^{46}$

The citation of the verse shows three facts: unity of mankind under one God, particularity of religions brought by the prophets, and the roles of revelations in reconciling any differences among the followers of religions. It is the three that are called by Sachedina as the foundation of the Holy Quran on the religion pluralism. On the one hand, the concept in the Holy Quran does not deny particularity of various religions dealing with right practices and faiths. On the other hand, the conception of the Holy Quran gives an emphasis on the need for recognizing the unity of human beings in the creation and the necessity to develop a better understanding among the followers of inter-religions. ${ }^{47}$ Sachedina adds that the main argument of the religion pluralism in the Holy Quran is based on the relation between private faith and its public projection in the political community of Islam. Concerning with the private faith, the Holy Quran has non-interventionist attitude. And dealing with the faith pub-

${ }^{44}$ Abdul Aziz Sachedina, Kesetaraan..., 49.

${ }^{45}$ Abdul Aziz Sachedina, Kesetaraan..., 49.

${ }^{46} \mathrm{Al}-\mathrm{Qur}$ 'an, 2 (al-Baqarah): 213. Besides this verse, the Holy Quran also gives much bases for the freedom to have faiths such as QS. 2 (al-Baqarah): 256, QS. 10 (Yünus): 108, QS. 17 (al-Isra'): 15, and QS. 18 (Al-Kahfi): 29.

${ }^{47}$ Abdul Aziz Sachedina, Kesetaraan..., 51. 
lic projection, the attitude of the Holy Quran is based on the coexistence principle. $^{48}$

Interestingly, among the supporters of pluralism is Gamal al-Banna (1920-2013), an activities of a militant organization, Muslim Brotherhood. According to Gamal al-Banna, the Holy Quran has talked about pluralism when confirming the attitude of accepting religions other than Islam to live together with. The acceptance is based on two reasons: the history and objective. The history is based on the relationship of three big religions: Judaism, Christianity, and Islam. Through historical approach, the Islamic ummah may understand that these three religions actually were born from one Father and many mothers. The One Father here is Abraham. It is through Abraham that prophets becoming of the three religions were born. ${ }^{49}$

Prophet Abraham, a figure living in XVIII BC, was born in Iraq and lived a long time in Ur, a city in Caledonia. He lived from one place to another between Egypt and Palestine, and passed away in Beersheba. His wife, Sarah, was sterile. This resulted him to marry with an Egypt girl, named Hajar. It is from this marriage between Abraham and Hajar, Ismail was born. The birth of Ismail caused Sarah to be jealous and asked Abraham to separate Hajar and her son from her. Abraham then brought Hajar and her son to Hijaz area. In this area, Hajar and Ismail lived together, meanwhile Abraham left them alone and returned to his homeland. Then Ismail grew adult and married with a girl from Adnan ethnic group. Ismail then became the leader of the ethnic group. The line of Ismail's descendants later bore the carrier of the Islam treatise, namely Muhammad, the son of Abdullah.

\footnotetext{
${ }^{48}$ Abdul Aziz Sachedina, Kesetaraan..., 51.

${ }^{49}$ Gamal al-Banna, Doktrin Pluralisme dalam al-Qur'an, trans. Taufiq Damas, Jakarta: Menara, 2006, 28.
} 
Besides Ismail, the prophet Abraham also had a son from his first wife, Sarah. It is through the path of Ishak that Bani Israil subsequently was formed, and from Bani Israil the prophets and the messengers carrying treatises for the ummah were born. The Prophets Mose and Christ are the carriers of Judaism and Christianity's treatises, respectively. The may be included the descendants of Abraham through the path of Ishak. Therefore, actually the three religions, Judaism, Christianity and Islam were born from one Father. It is pity that in the development, the relationship among the three Semitic religions has gone up and down, event, have had long conflicts.

The objective reason returns to the point of view of Islam of the concept of God as the Creator of the nature and all of the contents. In the concept of Islam, God is the creator of the nature and the former of human characters. God is the source of ideal values, such as wisdoms, justice, peace, and the like. It is He that has descended all religions from Adam to Muhammad. Consequently, it is improper if the fellow followers of religions conflict one another. This because, objectively God generated all religions and sent the prophets in accordance with different conditions of societies in each time period. It is this objective reason that Gamal al-Banna states that the Holy Quran never considers the religion plurality as a sensitive problem, due to the fact that all religions are created by God..$^{50}$ Then, Gamal al-Banna states that the attitude of Islam to the religion plurality stand above the equality, tolerance, complementation principle. Religion plurality is better than one religion, because one religion will not be able to respond the dynamics of humanity.

${ }^{50}$ Abdul Aziz Sachedina, Kesetaraan..., 35. 


\section{Conclusion}

On the basis of the previous descriptions, it can be concluded that pluralism in the present context has really become a challenge for the followers of Semitic religions. The history of inter-followers relations of Semitic religions coloured by long term conflicts has been used as the reason to formulize the pluralism teaching. Therefore, the thinkers of Semitic religions are always trying to formulize the pluralism concept among strong exclusivism in having a faith. They understand this pluralism not limited to the terms of plurality, diversity, passive tolerance, and religions relativism, but pluralism shouldbe understood as a concept that teaches that each follower of a religion should recognize the existence of other different religions. Inter-followers of religions should also be actively involved in understanding any differences and be committed to find out similarities and differences. If this understanding is reached, it is no wonder if they will be involved in many scientific forums and activities of interculture and religion dialogues. Therefore, pluralism necessitates some willingness inter-followers of Semitic religions to speak and listen to one another dialogically.

The dialogues to be developed not only theological ones, but also those for life, and for social activities, for sharing religious experiences, praying together and other informal encounters. These dialogic attitudes show some willingness and openness of each follower of each religion to criticize and to be criticized. This openness reflects the existence of awareness of a relativity of view and interpretation of religious texts. The thinkers and followers of Semitic religions should also know the importance of such internal relativism. It is though this kind of understanding that they will not be trapped in truth claim. But it should be admitted that among the thinkers, there are some who understand that pluralism is the acknowledgment of the truth of other religions. This attitude should 
not be theologically understood since each religion teaches a unique concept. Therefore, a statement that other religions should also teach truth and salvation should be understood in the anthropological and sociological contexts.

\section{Bibliography}

Ali, K. A Study of Islamic History, New Delhi: Idaraiyati Adabiyati, 1980.

Ali, Ameer. A Short History of the Saracens, New Delhi: Kitab Bhavan, 1981.

Ali, A. Mukti. Agama, Universitas, dan Pembangunan. Bandung: Badan Penerbit IKIP, 1971.

Arkoun, Mohammed. Islam Kontemporer Menuju Dialog Antaragama, trans. Ruslani. Yogyakarta: Pustaka Pelajar, 2001.

Armas, Adnin. "Gagasan Frithjof Schuon tentang Titik Temu Agama-agama," Islamia, Volume I, Number 3 (September-Nopember 2004), 9-18.

Badron, Sani. "Ibn 'Arabi tentang Pluralisme Agama," Islamia, Volume I, Number 3 (September-Nopember 2004), 30-48.

Al-Banna, Gamal. Doktrin Pluralisme dalam al-Qur'an, trans. Taufiq Damas. Jakarta: Menara, 2006.

Benner, John R. "Religion," in Encyclopedia Americana, Volume 29. CanadaUSA: American Sorporation, 1978.

Dean, Thomas (ed). Religious Pluralism and Truth: Essays on Cultural Philosophy of Religion. Albany: State University of New York Press, 1995.

Coward, Harold. Pluralism Challenge to World Religion. Maryknoll, NY: Orbis Books, 1985.

Hick, John. "Trinity and Incarnation in the Light of Religious Pluralism," in Three Faith

One God: A Jewish,Christian, Muslim Encounter, eds. John Hick and Edmund S. Meltzer. Albany: State University of New York Press, 1989, 197-199.

Hick, John. Tuhan Punya Banyak Nama, trans. Amin Ma'ruf and Taufiq Aminuddin. Yogyakarta: DIAN/Interfidei, 2006.

Flew, Anthony. A Dictionary of Philosophy, New York: St. Martin's Press, 1984. Hastings, James. "Pluralism," Encyclopedia of Religion and Ethics, Volume X, ed. James Hastings. New York: Charles Scribner's Sons, 1955.

Hornby, A. S., et. al. The Oxford Advanced Learner's Dictionary of Current English. Oxford: Oxford University Press, 1984. 
Kariel, Henry S. "Pluralism," International Encyclopedia of the Social Sciences, Volume 11, ed. David L. Sills, New York: The Macmillan Company and The Free Press, 1996.

Kimbal, Charles. Kala Agama Jadi Bencana, trans. Nurhadi. Bandung: Mizan, 2003.

Kirani, Asrori S. "Jembatan Ayat Keras dan Lunak," Gatra, Number. 10, Volume XIV (17-23 January 2008), 44-45.

Koyama, Kosuke. "A Theological Reflection on Religious Pluralism," in http://www.findarticles.com/cf_0/m2065/2_51/56063939/ print.jhtml, (8 Pebruari 2003).

Misrawi, Zuhairi. Al-Qur'an Kitab Toleransi: Inklusivisme, Pluralisme, dan Multikulturalisme. Jakarta: Fitrah dan Perhimpunan Pengembangan Pesantren dan Masyarakat, 2007.

Al-Mu'āfirīi, Muhammad 'Abd al-Malik bin Hishām. Al-Sīrah al-Nabawiyah, Jilid I-II. Ttp: Dār al-Turāth al-'Arabī li al-Tabā'ah wa al-Nash, t.th.

Osman, Mohammed Fathi. Islam, Pluralisme dan Toleransi Keagamaan: Pandangan al-Qur'an, Kemanusiaan, Sejarah, dan Peradaban, trans. by Irfan Abu Bakar. Jakarta: PSIK Universitas Paramadina, 2006.

Parson, Gerald (ed). The Growth of Religious Diversity Britanian from 1945. London: Routledge, 1993.

Rachman, Budhy Munawar. Islam Pluralis: Wacana Kesetaraan Kaum Beriman. Jakarta: Paramadina, 2001.

Sachedina, Abdul Aziz. Kesetaraan Kaum Beriman: Akar Pluralisme Demokratis dalam Islam, trans. by Satrio Wahono, Jakarta: Serambi, 2002.

Seager, Richard Huges (ed). The Dawn of Religious Pluralism: Voices from the World Parliament of Religion 1893, Illionis: Open Court Publishing Company, 1993.

Schuon, Frithjof. Understanding Islam, London: Unwin Paperbacks, 1981.

Smith, Huston. Agama-agama Manusia, trans. Saafroedin Bahar. Jakarta: Yayasan Obor Indonesia, 1991.

Thoha, Anis Malik. "Seyyed Hossein Nasr Mengusung Tradisionalisme Membangun Pluralisme Agama,” Islamia, Volume I, Number 3 (September-Nopember 2004), 19-28.

Watt, W. Montgomery. Muhammad Prophet and Statesmant. London: Oxford University Press, 1969. 